\title{
TECHNO-FUNCTIONAL, TEXTURAL AND SENSORIAL PROPERTIES OF FRANKFURTERS AS AFFECTED BY THE ADDITION OF BEE POLLEN POWDER
}

\author{
Sasa M. Novakovic, Ilija V. Djekic, Mirjana B. Pesic, Aleksandar Z. Kostic, Danijel D. Milincic, Igor B. Tomasevic \\ University of Belgrade, Faculty of Agriculture, Belgrade, Serbia
}

Keywords: texture, sensory, Warner-Bratzler, emulsion, FTIR-ATR

\begin{abstract}
The objective of this study was to determine whether the addition of different pollen powder concentrations (0.5; 1.0 and $1.5 \mathrm{~g} / 100 \mathrm{~g}$ ) had an influence on techno-functional, textural and sensorial traits of frankfurters. Examining the techno-functional characteristics of pollen, a conclusion was reached that the higher the concentration, the higher the emulsification and better techno-functional properties. Also, FTIR-ATR analysis has shown that specific pollen molecules provided good emulsifying properties of sausages. On the other hand, sensory analysis showed that sausages with the addition of $1.0 \%$ and $1.5 \%$ of pollen powder have a more pronounced floral odor. Warner-Bratzler shear force test has shown that the incorporation of pollen caused a more stable product throughout sixty days of storage than the control sample. It could be explained by the formation of more protein-protein interactions due to the addition of non-meat proteins in the formulation of frankfurters and obtaining a more stable product than the control one. All things considered, it can be concluded that pollen exhibits good techno-functional properties and could be utilized in the formulation of frankfurters with improved and steady techno-functional properties during two months of refrigerated storage.
\end{abstract}

\section{Introduction}

The most common type of emulsified meat products in the world are frankfurters [1]. The world leader in the number of different varieties and the birthplace of frankfurters is Germany. Their popularity is reflected by the convenience in preparation, tastefulness and time-saving. The wide variety in physicochemical properties of emulsions is affected by the diversity of components used during technological process of the production of sausages. Emulsions, also called meat batters, are a complex mix of different systems of dissolved proteins and salts, suspensions, gels made from myofibrillar proteins and emulsions that contain stabilized fat in a gel and fat which is partially present in liquid form [2].

One of the most important quality parameters of the emulsified meat products, such as frankfurters, is emulsion stability. It is highly dependant on the amount of fat and water, as well as myofibrillar proteins, previously extracted from the muscle tissue. Mechanical energy from cutter knives destroys sarcolemma and additives such as nitrite salt and phosphates and activate the protein released. The solubilized protein simultaneously immobilizes the water and emulsifies the added fat, stabilizing them in a tridimensional matrix [2].

Nowadays, there is a growing concern in the meat industry to produce healthier products and to change the perception of them as being unhealthy. Thus, many natural additives such as mushroom decoctions [3,4], mixed extracts of green tea, olive leaves and stinging nettle [5], garlic extract [6], are used for the production of sausages, in order to partially or totally replace the use of commer- cial antioxidants. Two key processes take a part in this technology: reformulation, by the reduction of ingredients that some consumers perceive as unhealthy (commercial antioxidants, nitrites and sodium chloride) and enriching the product with highly nutritious compounds that consumers perceive as health-beneficial. However, the question arises how these extracts affect the texture, techno-functional (emulsifying) and sensory properties of sausages.

Pollen is a natural product that contains a high amount of nutrients and bioactive compounds, such as polyphenols and flavonoids [7], which give it excellent antioxidant activity. Pollen, as a multi-component natural product, contains significant quantities of proteins, carbohydrates and lipids. These constituents give pollen good emulsifying, foaming and gelling properties $[7,8]$. Therefore, this complex structure of pollen allows its application in the formulation of numerous food products. Until now, several food products such as yogurt [9], cheese [10], bread [11], etc. have been enriched with pollen. Additionally, it is known that lyophilized pollen polyphenol extracts have been added to sausages [12], as well. However, to the best of our knowledge, it has never been investigated before how pollen powder affects the texture and sensory properties of meat products. Unlike pollen polyphenol extract, which has only antioxidant potential, pollen powder as a multi-component system can have a multifunctional impact in the production of high-fat products such as frankfurters.

Therefore, the objective of this research was to characterize bee pollen powder and frankfurters containing 
it using FTIR-ATR. Also, this study aimed to investigate techno-functional properties of pollen in three different concentrations and to determine the influence of pollen addition on the textural and sensorial traits of the final product.

\section{Objects and methods}

Bee-collected pollen (hereafter referred as pollen) was purchased from local beekeepers situated in East Serbia. According to the producers' declaration, the pollen predominantly originated from rapeseed (Brassica napus) and ash tree (Fraxinus spp.).

\section{Techno-functional properties of pollen}

Techno-functional properties such as emulsifying and foaming properties, as well as water/oil absorption capacity (WAC/OAC) were determined according to the methods previously described by [13]. Both, emulsifying and foaming properties were determined for three different pollen concentration $(0.5 ; 1 ; 1.5 \mathrm{~g} / 100 \mathrm{~g}$ aqueous dispersion of pollen sample at $\mathrm{pH} \mathrm{7)}$ at which pollen was added to Frankfurter-type sausages.

\section{Frankfurter's formulations}

Sausages were manufactured in a commercial meat factory (BigBull Foods, Bačinci, Serbia). Fresh pork meat (Biceps femoris), without connective tissue, pork back fat and ice were used in the amounts of 50\%, 25\% and 25\%, respectively. Meat was transferred to a bowl chopper, and salt and polyphosphate were added. After that, meat tissue was comminuted for 3 minutes at low speed, in order to extract myofibrillar proteins until the temperature reached $6^{\circ} \mathrm{C}$, when other ingredients were slowly added. The temperature of the mixture was not allowed to exceed $12^{\circ} \mathrm{C}$ [14]. Pollen is added in the amount of $0.5 \%$ (T1), $1.0 \%$ (T2) and $1.5 \%$ (T3). Each treatment was repeated in triplicate, as well as a control sample, only without pollen in its formulation. These mixtures were blended until they reached $12^{\circ} \mathrm{C}$. After preparation of emulsions, sausages were stuffed into polyamide casings (Edicas, Girona, approximate $22 \mathrm{~mm}$ diameter) and cooked at $80^{\circ} \mathrm{C}$ in a smokehouse (EL-C-Q 1900, Kerres Anlagenststeme GmbH, Backnang, Germany) until the core temperature of $72^{\circ} \mathrm{C}$. The cooked samples were cooled using the shower and placed in vacuum bags (4 frankfurters approximately $50 \mathrm{~g}$ each) and coded according to appropriate treatment production.

\section{FTIR-ATR analysis}

FTIR-ATR spectra of pollen powder and small portions of frankfurters enriched with pollen were recorded by using an ALPHA FTIR spectrophotometer (Bruker) equipped with a Platinum ATR diamond module. The FTIR-ATR recording parameters were as follows: the spectral resolution was $4 \mathrm{~cm}^{-1}$; 32 scans; absorbance mode was in the range of 400 to $4000 \mathrm{~cm}^{-1}$. Date collection and analysis were performed using OPUS7.5 software.

\section{Warner-Bratzler Shear force measurement}

Textural properties of frankfurters were conducted using Warner-Bratzler Shear force (WBSF) test [15]. For the purpose of the investigation through this method, WarnerBratzler ' $\mathrm{V}$ ' slot blade was attached to the Universal testing machine (TA.XT Stable Micro System Corporation, UK). The load cell capacity was $50 \mathrm{~kg}$, while shearing speed was $1.50 \mathrm{~mm} \mathrm{sec}^{-1}$. The parameter obtained in this method was the maximum shear force $(\mathrm{N})$ and represents the highest peak of the curve, which is the maximum resistance of the sample to shearing. At least six specimens were tested from each sample (about 24 per one treatment). All analyses were done in triplicate.

\section{Sensorial traits of frankfurters}

Five trained and experienced panel members were selected to participate in the development of sensory profiles for the three different concentrations of pollen in frankfurters. They were chosen based on their ability to provide similar responses on repeated occasions, smell acuity, interest in the project and availability for the duration of the study. In order to ensure that panelists were not influenced in any way, no information with regard to the nature of the samples was provided. Panelists were reminded not to use perfumed cosmetics and to avoid exposure to foods and/or fragrances at least $30 \mathrm{~min}$ before evaluation sessions.

A 100-point category scale was used to measure the intensity of each sensory attribute (pork flavour, sweet, floral, woody, salty, juicy) for the different concentrations of pollen in frankfurters. One (1) on the category scale denoted the total absence of sensory attribute (e. g., no floral aroma), fifty (50) denoted a moderate presence and one hundred (100) denoted the most intense condition (e. g., extremely floral frankfurter aroma).

Frankfurters were sliced into $25-\mathrm{mm}$ slices and coded with a random three-digit code. The serving temperature was $40^{\circ} \mathrm{C}$. One frankfurter was served at a time. When served to the panel, a coded sample was placed on a white plastic tray. Care was taken to ensure uniformity of each sample (volume served and serving temperature) and both replication of the different samples. Samples were randomized to exclude any bias due to the position effect. Acquisition of evaluation scores and data analysis was performed by Smart Senso Box software (Smart Sensory Solutions S.r.l., Sassari, Italy). Panel members were provided with water at room temperature, toasted bread and apples, which served as palate cleansers in between evaluation sessions.

\section{Statistical analysis}

Statistical analysis software SPSS17.0 (Chicago, Illinois, USA) was used for data analysis. Data from techno-functional properties, FTIR and sensorial traits of frankfurters were tested using One-Way Anova, while textural characteristics were performed using Two-Way Anova with repeated measurements, considering treatments and storage 
as fixed effects and replicate as a random effect. Significant differences $(P<0.05)$ between means were determined by Tukey's HSD post-hoc test.

\section{Results and discussion}

\section{Techno-functional properties of pollen}

Emulsions and foams are usually crucial in the formation of texture and taste of food. Therefore, the potential application of pollen as a functional ingridient in different food products requires the identification of its technofunctional properties (Table 1). The values obtained for the emulsifying stability index (ESI) ranged from $14.04 \mathrm{~min}$ to $11.53 \mathrm{~min}$, whereas emulsifying activity index (EAI) varied from 58.59 to $156.60 \mathrm{~m}^{2} / \mathrm{g}$, that depending on the pollen concentration in aqueous dispersion. All pollen aqueous dispersions exhibited the complete absence of the ability to form stable foams. The observed characteristic confirmed the anti-foaming properties of pollen, which is in accordance with a previous report from [13]. The oil and water absorption capacities of analysed pollen were 1.5 and 0.9 $\mathrm{g} / \mathrm{g}$, respectively, which is in line with results reported by [13]. It can be concluded that pollen possesses excellent emulsifying properties, oil and water absorption capacities, which qualify it for application in meat products, primarily in heterogeneous colloidal products such as Frankfurtertype sausages where these features are desirable.

Table 1. Techno-functional properties of pollen sample

\begin{tabular}{|c|c|c|c|c|c|}
\multicolumn{5}{|c|}{ Techno-functional properties } \\
\hline Emulsifying properties & $\begin{array}{c}\text { Foaming } \\
\text { properties }\end{array}$ & $\begin{array}{c}\text { Water/Oil } \\
\text { absorption capacity }\end{array}$ \\
\hline ESI (min) & EAI $\left(\mathrm{m}^{2} / \mathrm{g}\right)$ & FS $(\%)$ & FC $(\%)$ & $\begin{array}{c}\text { WAC } \\
(\mathrm{g} / \mathrm{g})\end{array}$ & $\begin{array}{c}\text { OAC } \\
(\mathrm{g} / \mathrm{g})\end{array}$ \\
\hline $\mathbf{1 4 . 0 4} \pm \mathbf{1 . 6 6}$ & $\mathbf{5 8 . 5 9} \pm \mathbf{1 0 . 7 0}$ & n.d. & n.d. & & \\
\hline $\mathbf{1 1 . 5 3} \pm \mathbf{0 . 3 3}$ & $\mathbf{1 1 2 . 2 6} \pm \mathbf{8 . 2 4}$ & n.d. & n.d. & $\mathbf{9 . 1} \pm \mathbf{0 . 2}$ & $\mathbf{8 . 5} \pm \mathbf{0 . 1}$ \\
\hline $\mathbf{1 2 . 9 3} \pm \mathbf{0 . 2 6}$ & $\mathbf{1 5 6 . 6 0 \pm 2 1 . 8 7}$ & n.d. & n.d. & & \\
\hline
\end{tabular}

* "n.d." - not detected; The results in the table are presented as means \pm standard deviations (mean $\pm \mathrm{SD} ; \mathrm{n}=3$ ); Abbreviations: $\mathrm{ESI}$ - emulsion stability index; EAI - emulsion activity index; FS - foam stability; FC - foam capacity; WAC - water absorption capacity; OAC - oil absorption capacity

\section{FTIR-ATR analysis}

FTIR-ATR spectra of frankfurters and pollen-enriched frankfurters show the same absorption bands that mainly correspond to proteins, lipids and water (Figures 1a, b, c, d). The broad band at $3272 \mathrm{~cm}^{-1}$ corresponding to $\mathrm{O}-\mathrm{H}$ stretching vibrations which are most likely originated from water, because the ratio of added ice during the production of frankfurters was as much as $25 \%$. Vibrations observed in the FTIR spectrum at $2960 \mathrm{~cm}^{-1} ; 2920-2924 \mathrm{~cm}^{-1}$ and $2852 \mathrm{~cm}^{-1}$ originated from $\mathrm{CH}_{3}$ asymmetric, $\mathrm{CH}_{2}$ asymmetric and $\mathrm{CH}_{2}$ symmetric stretching and mainly belong to lipids $[16,17]$. The strong and dominant peaks at $1650 \mathrm{~cm}^{-1}$ (Amide I) and $1540 \mathrm{~cm}^{-1}$ (Amide II) originated from $\mathrm{C}=\mathrm{O}$ stretching, $\mathrm{N}-\mathrm{H}$ bending and $\mathrm{C}-\mathrm{N}$ stretching of proteins. Peak at $1736 \mathrm{~cm}^{-1}$ was corresponding to $\mathrm{C}=\mathrm{O}$ carbonyl stretching which can be derived from cholesterol and tri- acylglycerol esters [17]. Vibration at $1455 \mathrm{~cm}^{-1}$ represents $\mathrm{C}-\mathrm{O}-\mathrm{H}$ bending of lipids and proteins, while vibration at $1396 \mathrm{~cm}^{-1}$ can be linked with $\mathrm{COO}^{-}$symmetric stretching of fatty acids. Peak at $1240 \mathrm{~cm}^{-1}$ can be connected with $\mathrm{PO}^{2-}$ asymmetric stretching indicating the presence of nucleic acids (mainly), phospholipids, phosphorylated proteins in the analyzed samples $[16,17]$. Vibrations at $1172 \mathrm{~cm}^{-1}$ may be derived from $\mathrm{CO}$ stretching vibration of $\mathrm{C}-\mathrm{OH}$ groups of serine, threonine and tyrosine residues [16]. Peak at $1082 \mathrm{~cm}^{-1}$ can be correlated with $\mathrm{PO}^{2-}$ symmetric stretching; $\mathrm{C}-\mathrm{O}$ stretching and $\mathrm{C}-\mathrm{H}$ deformation which was corresponding to the nucleic acids, phospholipids and glycogen $[16,17]$.

Spectrum of pollen powder (Figure 1e), showed dominant peaks belonging to the region of $3000-2800 \mathrm{~cm}^{-1}$ (oil's regions); $1700-1500 \mathrm{~cm}^{-1}$ (protein region) and $1200-900$ $\mathrm{cm}^{-1}$ (carbohydrate regions) [7,18,19]. A strong peak at $1025 \mathrm{~cm}^{-1}$ indicated the presence of polysaccharides, and less pronounced bands in the range of 700 to $900 \mathrm{~cm}^{-1} \mathrm{can}$ originate from $\mathrm{C}-\mathrm{O}-\mathrm{C}$ and $\mathrm{C}-\mathrm{OH}$ vibrations $[7,20]$. Broad band in the range of $1420-1370 \mathrm{~cm}^{-1}$ can originate from $\mathrm{C}-\mathrm{H}$ deformation vibrations of lipids and cellulose, while region between $1350-1200 \mathrm{~cm}^{-1}$ can be connected with $\mathrm{N}-\mathrm{H}$ deformation and $\mathrm{C}-\mathrm{H}$ stretching of amide III $[19,21]$. In the spectra of pollen-enriched frankfurters (Figures $1 \mathrm{~b}$, c, d), bands originated from frankfurter were dominant, which in most of cases overlap bands originating from pollen. Thus, through this approach cannot be concluded whether there were strong chemical interactions between constituents of frankfurter and pollen or not.

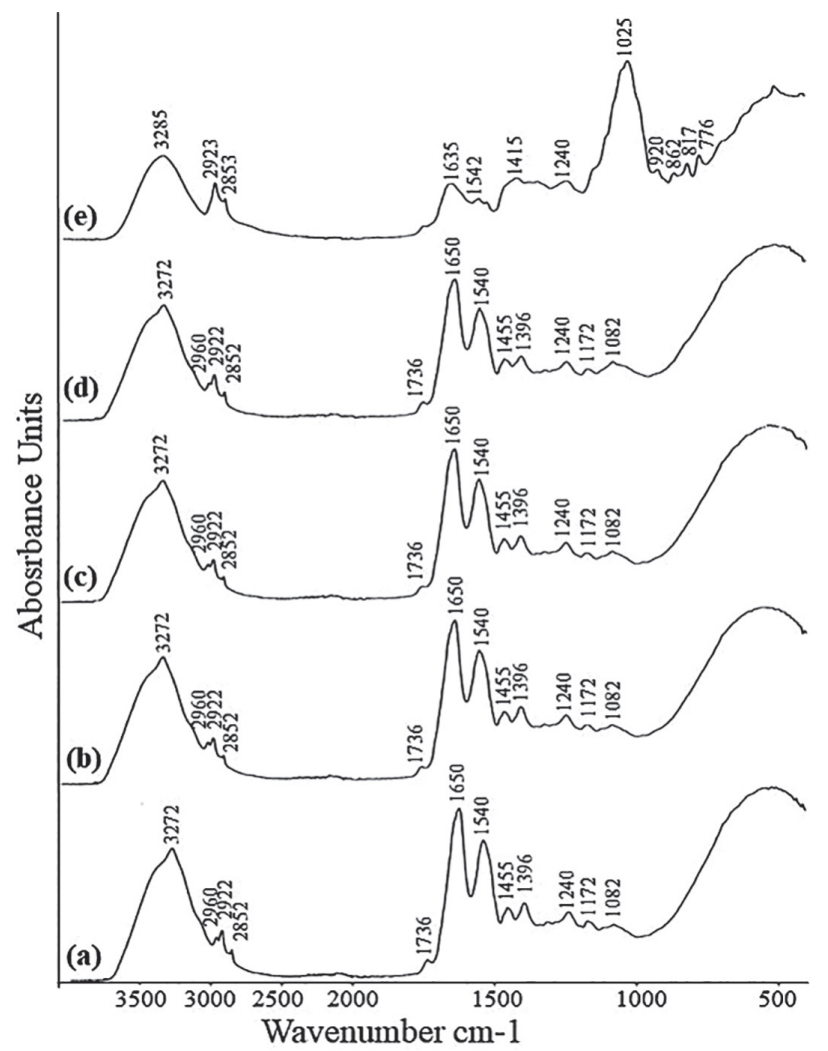

Figure 1. FTIR-ATR spectre of: (a) frankfurters without pollen; (b) frankfurters with $0.5 \%$ pollen; (c) frankfurters with $1 \%$ pollen; (d) frankfurters with $1.5 \%$ pollen; (e) pollen powder 


\section{Warner-Bratzler shear force of sausages}

One of the main characteristics of meat products that influence consumers' purchasing decision is toughness/ tenderness [22]. Three different concentrations of pollen added did not cause a statistically significant difference ( $P>0.05$ ) between treatments, during 40 days of storage period, regarding Warner-Bratzler Shear force values $(\mathrm{N})$. On the $60^{\text {th }}$ day, significant difference $(\mathrm{P}<0.05)$ was observed between control group and treatments with pollen (T1, T2, T3) (Table 2). Usually, the higher the non-meat protein content in sausages, the harder and chewier texture of sausages. In this case, pollen, as a natural ingredient, is rich in protein, but also in lipid content [13]. Hence, these components are crucial in the formation of emulsions, as well as the texture and taste of the final product.

Table 2. Warner-Bratzler Shear force of frankfurters

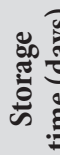

C

T1

T2

T3

\begin{tabular}{|c|c|c|c|c|c|}
\hline & 1 & $2.76 \pm 0.18^{\mathrm{a}, \mathrm{A}}$ & $2.86 \pm 0.07^{\mathrm{a}, \mathrm{A}}$ & $2.81 \pm 0.15^{\mathrm{a}, \mathrm{A}}$ & $2.81 \pm 0.16^{\mathrm{a}, \mathrm{A}}$ \\
\hline & 20 & $2.73 \pm 0.17^{\mathrm{a}, \mathrm{A}}$ & $2.85 \pm 0.2^{\mathrm{a}, \mathrm{A}}$ & $2.87 \pm 0.17^{\mathrm{a}, \mathrm{A}}$ & $2.89 \pm 0.16^{\mathrm{a}, \mathrm{A}}$ \\
\hline & 40 & $2.72 \pm 0.17^{\mathrm{a}, \mathrm{A}}$ & $2.85 \pm 0.2^{\mathrm{a}, \mathrm{A}}$ & $2.87 \pm 0.17^{\mathrm{a}, \mathrm{A}}$ & $2.89 \pm 0.16^{\mathrm{a}, \mathrm{A}}$ \\
\hline & 60 & $2.24 \pm 0.15^{\mathrm{a}, \mathrm{B}}$ & $3 \pm 0.21^{b, A}$ & $3.04 \pm 0.23^{b, A}$ & $3.14 \pm 0.2^{\mathrm{b}, \mathrm{A}}$ \\
\hline
\end{tabular}

${ }^{1}$ Abbreviations: $\mathrm{C}=$ control group of frankfurters, without pollen; $\mathrm{T} 1=\mathbf{0 . 5} \%$ pollen added in frankfurters; $\mathrm{T} 2=1.0 \%$ pollen added in frankfurters; T3 $=1.5 \%$ pollen added in frankfurters; TBARS Thiobarbituric acid reactive substances value.

${ }^{2}$ Values are displayed as arithmetic means \pm standard errors of means (mean \pm SEM). Values with different lowercase letters (a-b) in the same row differ significantly $(P<\mathbf{0 . 0 5})$. Values with different uppercase letters $(\mathrm{A}-\mathrm{C})$ in the same column differ significantly $(P<0.05)$.

Throughout the period of storage, there was no statistically significant difference $(\mathrm{P}>0.05)$ within treatments with the addition of pollen, while in the control group there was a significant $(\mathrm{P}<0.05)$ decrease. Excellent emulsifying properties, oil and water absorption of pollen contribute to obtaining stable product throughout storage, especially when it comes to such a long period as two months are. Also, it is an indicator of the good stability of frankfurters with pollen added during storage. However, although there were no statistical differences, a slight tendency toward an increase in the shear work appears with the longer storage period in treatments with pollen. A similar trend in the increase of WBSF values in sausages reported [23], as well as [24], who explained that this trend was the consequence of the moisture loss and the mechanism that favors hardening of the sausages, such as the formation of cross-links in proteins. In our study, it could be explained with the additional value of proteins added via pollen and more crosslinks formed throughout the storage period.

\section{Sensorial traits of frankfurters}

Pork flavor was defined as the amount of pork flavor identity. Major notes for pork flavor identity consist of roasted notes that round and fully aromatic and generally associated with pork fat that has been broiled. Bloody and serumy notes that are associated with blood of cooked meat and closely related to metallic aromatic are also present. Third major pork flavor note is liver-like and associated with cooked organ meat, mostly liver. Finally, pork flavor can be described with green-haylike notes (brown/ green dusty aromatic associated with dry grasses, hay, dry parsley and tea leaves) and umami notes (flat, salty, somewhat brothy with the taste of glutamate, salts of amino acids and nucleotides) [25]. Unsurprisingly, frankfurter samples without the addition of pollen were perceived by the panelists as samples with the most intense pork flavor aroma (70.5), while the pork flavor intensity was only mild for T1 samples (58) and moderate for T2 and T3 samples (48.1) (Figure 2).

Floral aroma was described as taste and smell associated with different flowers [26]. We can conclude that with the addition of pollen into frankfurters they have obtained floral notes that have not been present in control samples (12). As much as $0.5 \%$ of pollen increased the sensation of floral aroma by two fold (25) in T1 samples and were moderately perceived in both T2 (44) and T3 (45) samples. The fact that floral notes reached a plateau with the addition of $1 \%$ of pol-

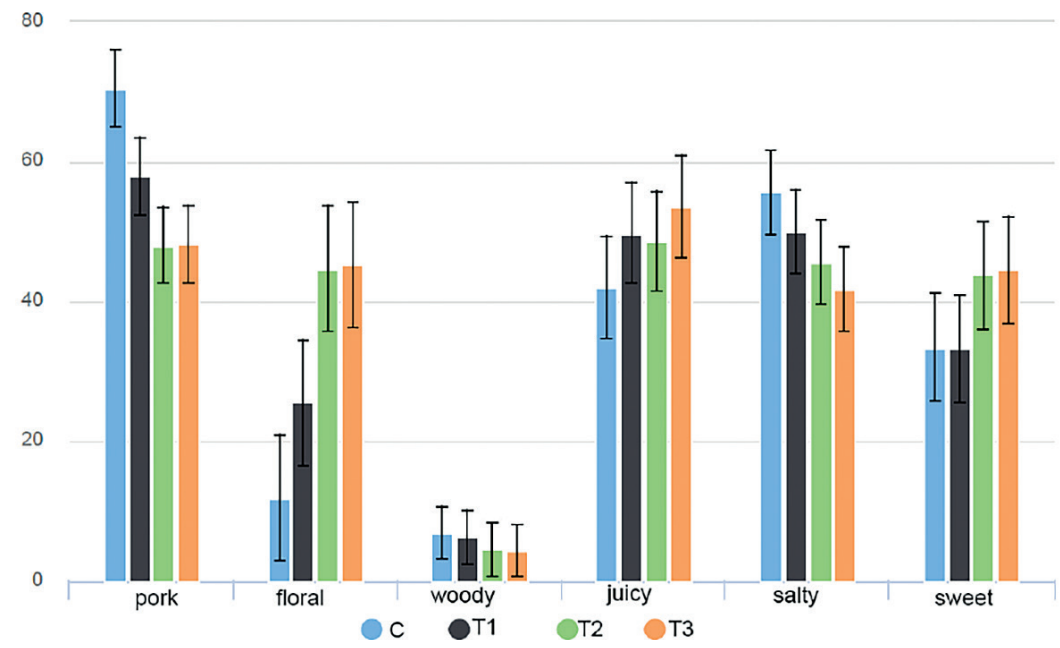

Figure 2. Sensorial traits of frankfurters

${ }^{1}$ Abbreviations: $\mathrm{C}=$ control group of frankfurters, without pollen; $\mathrm{T} 1=0.5 \%$ pollen added in frankfurters; $\mathrm{T} 2=1.0 \%$ pollen added in frankfurters; $\mathrm{T} 3=1.5 \%$ pollen added in frankfurters. 
len is actually a good thing since the actual "taste" of flowers can be off-putting because, at the end of the day, people don't eat flowers that often. Food that is flavored with floral notes usually push too far. Florals are most pleasing to the palate when they are well balanced and offset by thick rich texture of food like the one present in frankfurters.

\section{Conclusion}

The incorporation of pollen resulted in obtaining a stable product during two months of chilled storage, without any adverse effect regarding textural characteristics.
Although excellent emulsifying properties of pollen were obtained, a certain limitation in terms of sensory properties occurs, especially due to obtaining specific notes that could provoke certain negative ratings from consumers. FTIR-ATR has shown a multi-component structure of pollen powder which provides good emulsifying properties to sausages and obtaining good consistency. All things considered, each pollen concentration could be used as a potential natural additive that contributes to obtaining a stable emulsion and consistent meat product during the two months of refrigerated storage.

\section{REFERENCES}

1. Fernández-López, J., Lucas-González, R., Viuda-Martos, M., Sayas-Barberá, E., Navarro, C., Haros, C. M., Pérez-Álvarez, J. A. (2019). Chia (Salvia hispanica L.) products as ingredients for reformulating frankfurters: Effects on quality properties and shelflife. Meat Science, 156, 139-145. https://doi.org/10.1016/j. meatsci.2019.05.028

2. Feiner, G. (2006). Meat products handbook: Practical science and technology. Elsevier.

3. Novakovic, S., Djekic, I., Klaus, A., Vunduk, J., Djordjevic, V., Tomović, V. et. al. (2019). The Effect of Cantharellus Cibarius Addition on Quality Characteristics of Frankfurter during Refrigerated Storage. Foods, 8(12), Article 635. https://doi.org/10.3390/ foods 8120635

4. Novakovic, S., Djekic, I., Klaus, A., Vunduk, J., Đorđević, V., Tomovic, V. et. al. (2020). Application of porcini mushroom (Boletus edulis) to improve the quality of frankfurters. Journal of Food Processing and Preservation, 44(8), Article e14556. https://doi. org/10.1111/jfpp.14556

5. Alirezalu, K., Hesari, J., Yaghoubi, M., Khaneghah, A. M., Alirezalu, A., Pateiro, M., Lorenzo, J. M. (2021). Combined effects of $\varepsilon$-polylysine and $\varepsilon$-polylysine nanoparticles with plant extracts on the shelf life and quality characteristics of nitrite-free frankfurtertype sausages. Meat Science, 172, Article 108318. https://doi. org/10.1016/j.meatsci.2020.108318

6. Horita, C. N., Farías-Campomanes, A. M., Barbosa, T. S., Esmerino, E. A., da Cruz, A. G., Bolini, H. M. A. et. al. (2016). The antimicrobial, antioxidant and sensory properties of garlic and its derivatives in Brazilian low-sodium frankfurters along shelf-life. Food Research International, 84, 1-8. https://doi.org/10.1016/j. foodres.2016.02.006

7. Kostić, A., Milinčić, D., Barać, M., Ali Shariati, M., Tešić, Ž. Pešić, M. (2020). The Application of Pollen as a Functional Food and Feed Ingredient - The Present and Perspectives. Biomolecules, 10(1), Article 84. https://doi.org/10.3390/biom10010084 8. Thakur, M., Nanda, V. (2020). Exploring the physical, functional, thermal, and textural properties of bee pollen from different botanical origins of India. Journal of Food Process Engineering, 43(1), Article e12935. https://doi.org/10.1111/jfpe.12935 9. Karabagias, I. K., Karabagias, V. K., Gatzias, I., Riganakos, K. A. (2018). Bio-Functional Properties of Bee Pollen: The Case of "Bee Pollen Yoghurt". Coatings, 8(12), Article 423. https://doi. org/10.3390/coatings8120423

10. Abd Elhamid, A. M., Elbayoumi, M. M. (2017). Influence of bee pollen on the bioactive behavior, sensory and physicochemical properties of white cheese made from camel and cow milk mixture. Journal of Food Dairy Sciences, 8(11), 419-424.

11. Di Cagno, R., Filannino, P., Cantatore, V., Gobbetti, M. (2019). Novel solid-state fermentation of bee-collected pollen emulating the natural fermentation process of bee bread. Food Microbiology, 82, 218-230. https://doi.org/10.1016/j.fm.2019.02.007 12. de Florio Almeida, J., dos Reis, A. S., Heldt, L. F. S., Pereira, D., Bianchin, M., de Moura, C. et. al. (2017). Lyophilized bee pollen extract: A natural antioxidant source to prevent lipid oxidation in refrigerated sausages. LWT-Food Science Technology, 76, 299305. https://doi.org/10.1016/j.Iwt.2016.06.017

13. Kostić, A., Barać, M., Stanojević, S., Milojković-Opsenica, D., Tešić, Ž., Šikoparija, B. et. al. Physicochemical composition and techno-functional properties of bee pollen collected in Serbia. LWT-Food Science Technology, 62(1), 301-309. https://doi. org/10.1016/j.Iwt.2015.01.031

14. Costa-Lima, B. R. C., Canto, A. C. V. C. S., Suman, S. P., Conte-Junior, C. A., Silveira, E. T. F., Silva, T. J. P. (2014). Sex-specific effect of ractopamine on quality attributes of pork frankfurters. Meat Science, 96(2, Part A), 799-805. https://doi. org/10.1016/j.meatsci.2013.10.001

15. De Huidobro, F. R., Miguel, E., Blázquez, B., Onega, E. (2005). A comparison between two methods (Warner-Bratzler and texture profile analysis) for testing either raw meat or cooked meat. Meat Science, 69(3), 527-536. https://doi.org/10.1016/j.meatsci.2004.09.008

16. Candoğan, K., Altuntas, E. G., İğci, N. (2021). Authentication and Quality Assessment of Meat Products by Fourier-Transform Infrared (FTIR) Spectroscopy. Food Engineering Reviews, 13(1), 66-91. https://doi.org/10.1007/s12393-020-09251-y

17. Deniz, E., Güneş Altuntaş, E., Ayhan, B., İğci, N., Özel Demiralp, D., Candoğan, K. (2018). Differentiation of beef mixtures adulterated with chicken or turkey meat using FTIR spectroscopy. Journal of Food Processing Preservation, 42(10), Article e13767. https://doi.org/10.1111/jfpp.13767

18. Andrade, J., Pereira, C. G., de Almeida Junior, J. C., Viana, C. C. R., de Oliveira Neves, L. N., da Silva, P. H. F. et. al. (2019). FTIR-ATR determination of protein content to evaluate whey protein concentrate adulteration. LWT, 99, 166-172. https://doi. org/10.1016/j.lwt.2018.09.079

19. Kasprzyk, I., Depciuch, J., Grabek-Lejko, D., Parlinska-Wojtan, M. (2018). FTIR-ATR spectroscopy of pollen and honey as a tool for unifloral honey authentication. The case study of rape honey. Food Control, 84, 33-40. https://doi.org/10.1016/j.foodcont.2017.07.015

20. Kostić, A. Ž., Milinčić, D. D., Gašić, U. M., Nedić, N., Stanojević, S. P., Tešić, Ž. L., Pešić, M. B. (2019). Polyphenolic profile and antioxidant properties of bee-collected pollen from sunflower (Helianthus annuus L.) plant. LWT, 112, Article 108244. https://doi. org/10.1016/j.Iwt.2019.06.011

21. Kostić, A. Ż., Milinčić, D. D., Stanisavljević, N. S., Gašić, U. M., Lević, S., Kojić, M. O. at al. (2021). Polyphenol bioaccessibility and antioxidant properties of in vitro digested spray-dried thermally-treated skimmed goat milk enriched with pollen. Food Chemistry, 351, Article 129310. https://doi.org/10.1016/j.foodchem.2021.129310

22. Jin, S.-K., Choi, J. S., Yang, H.-S., Park, T.-S., Yim, D.-G. (2018) Natural curing agents as nitrite alternatives and their effects on the physicochemical, microbiological properties and sensory evaluation of sausages during storage. Meat Science, 146, 3440. https://doi.org/10.1016/j.meatsci.2018.07.032

23. Silva, F. A. P., Amaral, D. S., Guerra, I. C. D., Arcanjo, N. M. O., Bezerra, T. K. A., Ferreira, V. C. S. et. al. (2014). Shelf life of cooked goat blood sausage prepared with the addition of heart and kidney. Meat Science, 97(4), 529-533. https://doi.org/10.1016/j. meatsci.2014.03.018

24. Herrera, E. A. C. (2006). Contributions to the characterization of the black pudding of León and evolution of certain physical, chemical and microbiological parameters during its conservation under refrigeration.(theses of the dissertation) (In Spanish) 
25. Miller, R. K. (2012). Sensory Evaluation of Beef Flavor. Chapter in a book: Handbook of Meat, Poultry and Seafood Quality (pp. 173-191). Blackwell Publishing Ltd.

26. Galán-Soldevilla, H., Ruiz-Pérez-Cacho, M. P., Serrano Jiménez, S., Jodral Villarejo, M., Manzanares, A. B. (2005). Develop- ment of a preliminary sensory lexicon for floral honey. Food Quality and Preference, 16(1), 71-77. https://doi.org/10.1016/ j.foodqual.2004.02.001

\section{AUTHOR INFORMATION}

Sasa M. Novakovic - PhD candidate, MSc, teaching assistant, Animal Source Food Technology Department, Faculty of Agriculture, University of Belgrade. 6 Nemanjina, Zemun, 11080, Belgrade, Serbia. E-mail: sasha.novakovic@agrif.bg.ac.rs ORCID: https://orcid.org/0000-0002-0292-195X

Ilija V. Djekic — PhD, full professor, full professor, Department for Food Safety and Quality Management, Faculty of Agriculture, University of Belgrade. 6 Nemanjina, Zemun, 11080, Belgrade, Serbia.E-mail: idjekic@agrif.bg.ac.rs

ORCID: https://orcid.org/0000-0002-8132-8299

Mirjana B. Pesic - PhD, associate professor, associate professor, Department for Chemistry and Biochemistry, Faculty of Agriculture, University of Belgrade. 6 Nemanjina, Zemun, 11080, Belgrade, Serbia.E-mail: mpesic@agrif.bg.ac.rs

ORCID: https://orcid.org/0000-0001-9779-1686

Aleksandar Z. Kostic — PhD, assistant professor, Department for Chemistry and Biochemistry, Faculty of Agriculture, University of Belgrade. 6 Nemanjina, Zemun, 11080, Belgrade, Serbia.E-mail: akostic@agrif.bg.ac.rs

ORCID: https://orcid.org/0000-0002-1012-4029

Danijel D. Milincic - PhD candidate, MSc, teaching assistant, Department for Chemistry and Biochemistry, Faculty of Agriculture, University of Belgrade.6 Nemanjina, Zemun, 11080, Belgrade, Serbia.E-mail: milincic93@gmail.com

ORCID: https://orcid.org/0000-0002-2476-9426

Igor B. Tomasevic — PhD, associate professor, associate professor, Animal Source Food Technology Department, Faculty of Agriculture, University of Belgrade. 6 Nemanjina, Zemun, 11080, Belgrade, Serbia. E-mail: tbigor@agrif.bg.ac.rs

ORCID: https://orcid.org/0000-0002-1611-2264

* corresponding author

All authors bear responsibility for the work and presented data.

All authors made an equal contribution to the work.

The authors were equally involved in writing the manuscript and bear the equal responsibility for plagiarism.

The authors declare no conflict of interest. 